\title{
"Atlantic Gap or Network of Opportunities?" Spanish-American Cultural Relations, Women, and Diplomacy (1959-1975)
}

\author{
Moisés Rodríguez-Escobar ${ }^{1}$ and Francisco Rodríguez-Jiménez ${ }^{2}$ \\ ${ }^{1}$ Universidad de Salamanca \\ e-mail:moirguez@usal.es \\ ORCID iD: https://orcid.org/0000-0002-8721-4882 \\ ${ }^{2}$ Universidad de Extremadura; \\ Global Studies Project, Universidad de Salamanca. \\ ORCID iD: https://orcid.org/0000-0002-2580-7981
}

Submitted: 30 January 2018. Accepted: 10 November 2018

\begin{abstract}
The geopolitical context of what would later come to be called the "global village" made governments pay more attention to their external image and the public opinion of third-world countries. The previous emphasis on the development of military or economic alliances (hard power) was complemented with alternative views, other ways of connecting with different global societies (soft power). Relations between the United States and Spain did not escape this general dynamic. Here, we evaluate the extent to which this connection affected women's access to higher education in Spain. With the Residencia de Señoritas, there was a narrowing of the educational and cultural exchange relations between the two countries. After the abrupt cessation of the civil war, the establishment of the Fulbright program in the 1959-60 academic year allowed Spain to recover and to intensify the exchanges that had taken place since the beginning of the century. We will see what the fields of study in this prestigious exchange program were, and analyze to what extent the training received on the other side of the Atlantic facilitated the professional careers of the Spanish Fulbrigthers upon their return.
\end{abstract}

KEYWORDS: Fulbright Program; Cultural exchange; University students; Women; Education; Public diplomacy.

Citation / Cómo citar este artículo: Rodríguez-Escobar, Moisés and Rodríguez-Jiménez, Francisco (2019) “Atlantic Gap or Network of Opportunities?" Spanish-American Cultural Relations, Women, and Diplomacy (1959-1975)" Culture \& History Digital Journal, 8 (1): e008. https://doi.org/10.3989/chdj.2019.008

RESUMEN: ¿Brecha atlántica o red de oportunidades? Mujer, diplomacia y relaciones culturales hispano-estadounidenses.- El contexto geopolítico de lo que más tarde se llamaría la "aldea global" ha hecho que los gobiernos presten más atención a su imagen externa y a la opinión pública de los países del tercer mundo. El énfasis anterior en el desarrollo de alianzas militares o económicas (poder duro) se complementó con puntos de vista alternativos y otras formas de conectarse con diferentes sociedades globales (poder blando). Las relaciones entre Estados Unidos y España no escaparon a esta dinámica general. Aquí, evaluamos hasta qué punto esta conexión afectó al acceso de las mujeres a la educación superior en España. Con la Residencia de Señoritas, hubo un estrechamiento de las relaciones de intercambio educativo y cultural entre los dos países. Después del abrupto cese de la guerra civil, el establecimiento del programa Fulbright en el año académico 1959-60 permitió a España recuperar e intensificar los intercambios que habían tenido lugar desde principios de siglo. Veremos cuáles son los campos de estudio dentro de este prestigioso programa de intercambio y analizaremos hasta qué punto la capacitación recibida en el otro lado del Atlántico facilitó las carreras profesionales de los Fulbrigthers españoles a su regreso.

PALABRAS CLAVE: Programa Fulbright; Intercambio cultural; Estudiantes universitarios; Mujeres; Educación; Diplomacia pública.

Copyright: (C) 2019 CSIC. This is an open-access article distributed under the terms of the Creative Commons Attribution 4.0 International (CC BY 4.0) License. 


\section{NEW FORMS OF DIPLOMACY IN THE TWENTIETH CENTURY}

Among the many changes that occurred in the first half of the twentieth century, this article will focus on those that occurred in the field of international relations and diplomacy, specifically those related to the emergence of "mass society." This was a profound transformation that conditioned the way governments acted (Thompson, 1998: 4749). Political leaders started to recognize the need for substantial change in how they transmitted their ideas, both to the citizens of their countries and to other societies.

Within this general framework, cultural policies designed to project a specific message abroad in an attempt to affect public opinion in third-world countries emerged. The respective cabinets of information and propaganda were not alien to the practices of psychological warfare put into operation in the First World War. The objective at that time was to undermine and destroy the morale of the opposing side or, failing that, to attract the support of the uncommitted population.

The new cultural foreign policies, distinct from the classic geopolitical-HardPower-oriented, were justified by the need for a new approach to relations with the aforementioned mass society. Greater freedom and ease of access to information by the public was prompting governments to be more careful about what messages and images circulated. Times of peace afforded both the ability and the necessity for applying these principles; there was no need to focus attention on a specific enemy; the question, rather, was one of how to influence foreign opinion without provoking resistance (Niño, 2009: 34-36).

In recent decades, the number of works devoted to analyzing this phenomenon, known as cultural diplomacy or public diplomacy, has grown. We will not enter into the disquisitions about it here (Dizard, 2004) (Niño, 2009: 44). Though aware that several debates about the concept are still open, we will assume that public diplomacy is generally understood to mean "a strategy of information and persuasion aimed at an audience in order to get a favorable opinion for the foreign policy of a country or organization" (La Porte, 2007: 26).

Another analytical challenge arises when one tries to establish the boundary between public diplomacy and propaganda. The former term was first coined by Gullion in the 1960s, in the middle of the Cold War, almost as a euphemism for the latter, due to the negative connotations of the word propaganda (Cull and Rodríguez-Jiménez, 2015: 2). Although a fine line of distinction separates the two concepts, (even narrower in times of war...), it is useful to make the effort to differentiate them. As Jan Melissen points out:

Public diplomacy is similar to propaganda in that it tries to persuade people what to think, but it is fundamentally different from it in the sense that public diplomacy also listens to what people have to say (Melissen, 2005: 18).

These words highlight a fundamental issue in the differentiation of public diplomacy from other foreign poli- cy practices: it implies an openness to dialogue with the recipient. The recipient not only can decide whether to accept or reject the information being transmitted, but can compare, evaluate or even reject it.

These concepts are well known to Harvard professor Joseph Nye, who coined the term soft power in the nineties. According to this American author, soft power is persuasion, whereas hard power is characterized by imposition or coercion (Nye, 2004). Following along those lines, public diplomacy would constitute activities of soft power, while propaganda would fall more into the category of hard power (Noya, 2007: 131-132).

Beyond the different theoretical debates on these new concepts of international relations, ${ }^{1}$ this text undertakes to analyze Spanish-American cultural and educational transfers, in particular, those that affected women on both sides of the Atlantic. First, we will offer a brief description of the situation with education for women in Spain in the period before the Spanish Civil War. Only then can the processes of incorporation and stabilization affecting students in the later Spanish educational sphere be seen more broadly, as well as the extent to which this transformation was influenced by the connection with the United States.

\section{BELATED ACCESS TO HIGHER EDUCATION IN SPAIN}

With the passage of the Moyano Law in 1857, the legal framework that called for an extension of education for both sexes was established in Spain. The implementation of such noble desires would actually take decadesmany. Although at the beginning of the twentieth century the compulsory schooling age was increased from 6 to 12 years, it was still not assumed to be a right that the entire population could benefit from (Viñao 2004). From the time the law was enacted, incorporation of women in a more or less normalized manner would have to wait more than half a century. Even greater deficiencies prevailed in non-compulsory education.

The university, a minority option even among men, was seen as an even more rare and exceptional privilege in the case of women (Benso Calvo, 2003: 8). The university, a minority option even among men, was seen as a rare and exceptional privilege in the case of women (Benso Calvo, 2003: 8). In this sense, María Poveda Sanz distinguishes four phases or historical moments that women passed through toward obtaining full rights of access and obtaining the academic degree that, corresponding to the university course taken, would enable them to practice a qualified profession: the years before 1882 , from 1882 to 1888 , from 1888 to 1910 , and after 1910 (Poveda Sanz, 2014).

Until 1882, few in Spain conceived that women could study and work in the professions, especially those of the intellectual elite, and thus no legislation to this end had been passed. Even so, and though such cases were scarce, some did enter university studies in the male domains. The story of Concepción Arenal, who had to disguise her- 
self as a man to attend law classes, has remained a paradigmatic example (Folguera Crespo, 1997).

The increase in the presence of women in higher education was not an isolated phenomenon, but rather was closely related to their incorporation at the lower educational levels. Bearing this in mind, women who pursued university studies and practiced professions outside of the home during the first third of the 20th century would be integral to the female intellectual elite later on. In most cases, these were daughters of liberal professionals, of the upper classes, or with access to cultural property (Magallón Portolés \& Santesmases Navarro, 2007: 183).

From that point onward, the number of women in the university classrooms continued to grow. According to data from the Statistical Yearbooks of Spain, at the Central University the percentage of women for the 19311932 academic year was $8.80 \%$ of the total enrollment, a figure showing Madrid to be the place to which most women pursuing higher education went $(50.35 \%$ of university women were there).

This is where the possible connections and influences originating in the United States come into play. One of the highlights was produced through the big screen. The cinematographic productions of Hollywood began to be exhibited in Spain in the first third of the 20th century, a time in which about two-thirds of the population lived in the countryside, and more than half were illiterate
(Rodríguez, 2015). Perhaps for this reason the consumption of cinema, a relatively inexpensive leisure and that did not require training, was high in Spain (Aguinaga, 2010: 70-74).

Such films disseminated different images of women, and mindsets quite different from those prevailing in Spain. Thus would emerge "flappers," a term coined by F. Scott Fitzgerald to define a woman's style, with short skirt and short hair, urbanites without corsets or bustles, and lovers of jazz: a gust of the winds of feminine freedom wind. In the case of Spain, it would be necessary to wait for the decade of the twenties. Under the pervue of the Residencia de Señoritas appeared writers, intellectuals, artists, and women's associations that tried to join these winds of change and modernization, those whom Shirley Mangini called "the generation of modern women," who understood that education and work would bring them economic independence and freedom (Mangini, 2001).

This change of mentality helps make it understandable that during the Second Republic the participation of women in education increased. The last recorded academic year of the republican period was 1935-1936. Proportionally, the percentages of female university students continued to be small (11.57\% of the total in Madrid). But these were still hopeful data, showing an incipient interest of women determined to pursue university careers.

TABLE 1: Female university population in Spain (1914-1936)

\begin{tabular}{|c|c|c|}
\hline Academic years & Absolute figures of women enrolled in official free education & Percentage \\
\hline $1914-1915$ & 90 & 0.45 \\
\hline $1915-1916$ & 134 & 0.64 \\
\hline $1916-1917$ & 177 & 1.03 \\
\hline $1917-1918$ & 234 & 1.17 \\
\hline $1918-1919$ & 267 & 1.51 \\
\hline $1919-1920$ & 342 & 1.95 \\
\hline $1920-1921$ & 440 & 2.81 \\
\hline $1921-1922$ & 619 & 3.04 \\
\hline $1922-1923$ & 745 & 3.41 \\
\hline $1923-1924$ & 898 & 3.73 \\
\hline $1924-1925$ & 1,034 & 3.89 \\
\hline $1925-1926$ & 1,140 & 4.41 \\
\hline $1926-1927$ & 1,610 & 4.05 \\
\hline $1927-1928$ & 1,669 & 4.66 \\
\hline $1928-1929$ & 1,832 & 5.48 \\
\hline $1929-1930$ & 1,744 & 5.52 \\
\hline $1930-1931$ & 1,850 & 6.51 \\
\hline $1931-1932$ & 2,026 & 6.72 \\
\hline $1932-1933$ & 2,047 & \\
\hline
\end{tabular}

Source: Authors' own elaboration based on data from the Statistical Yearbooks of Spain from 1916 to 1935. 
In Table 1 can be seen here that access to the university for Spanish women came slowly. Well into the twenties, their presence in professional courses of study was barely perceptible: until 1926, the figure did not pass 4\%, and even then it did so timidly. Not until 1931 was the meager figure of $6 \%$ exceeded. (These figures refer to courses of study taken in the sciences, law, pharmacy, medicine, and philosophy and letters. Higher technical schools, where women also played a negligible role, are not included here) (Vázquez Ramil, 2012: 114-115).

\section{EDUCATIONAL INSTITUTIONS DURING THE FIRST THIRD OF THE 20TH CENTURY}

The aforementioned educational transformation was closely related to the work of the Instituto de Libre Enseñanza (ILE). This pedagogical project was developed in Spain for half a century (1876-1936), inspired by the Krausist philosophy introduced at the Central University of Madrid by Julián Sanz del Río, and had a significant impact on Spanish intellectual life (Cacho Viu 1997). Four institutions emerged from the modernizing drive and pedagogical renewal of the ILE: the Museo Pedagógico Nacional, the Junta para Ampliación de Estudios, the Residencia de Estudiantes, and the Instituto-Escuela. Of these, we are concerned with two-the Junta para Ampliación de Estudios and the Residencia de Estudiantes - with emphasis on the feminine aspect (Zulueta y Moreno 1993)

One of the main purposes of the ILE was to act organically in the training of teachers, promoting research and making connections with international scientific communities, which had been very limited until then. The first approach to the outside academic world took shape around 1906 with the creation of an office of technical information and foreign relations within the Ministry of Education. After this, and thanks to the work of José Castillejo, the Board for the Extension of Studies and Scientific Research (JAE) was created the following year. The Board was the organism that gave the greatest impulse to the development and dissemination of Spanish science and culture through a very active exchange program of teachers and students and the establishment of scholarships for study abroad (Sánchez, 2012: 15-34).

With regard to the relationship with the United States, this was helped by the interest in Spanish culture that had been awakening among Americans since the early twentieth century. Fundamental to this phenomenon were liaisons formed with such American institutions as the Rockefeller Institute, the Hispanic Society of America, the Institute of Spain (founded by Columbia University), the Institute of International Education, the American Association of Teachers of Spanish, and the American Council on Education (Puig-Samper, et al. 2002). The JAE significantly nurtured that flow of Spanish-American cultural and educational relationships through its scholarship program.

From 1908 to 1936, an average of 62 annual scholarships were granted, making for a total of 1,804 recipients. Of them, only $3.2 \%$ went to the United States. The prob- lem is that the participation of women in these programs, with the exception of the Residencia de Señoritas, was limited. Of every nine applications, only one was from a woman (Formentín Ibáñez y Villegas, 2007).

For its part, the Residencia de Estudiantes was created in 1910 under the auspieces of the JAE. The main idiosyncrasy of this "hostel for students" was its broad autonomy, as it was coordinated by a Board of Trustees. This allowed it to become a place of "study, work, research, and also of human and personal formation in the broadest sense of the concept" (Molero Pintado, 1985: 138). In the following pages we will on the Residencia de Señoritas (Cuesta, et al. 2016).

The creation in 1915 of this institution meant the emergence of the first official center designed to promote university education for women in Spain. The directorship of the center fell from the beginning into the hands of María de Maeztu. But her role was not limited to the administration of the center, as the JAE was entrusted with the difficult mission of negotiating the acquisition of some buildings that belonged to the International Institute, which was popularly known as the "college of the Bostonians" (Zulueta \& Moreno, 1993: 71-116).

\section{THE CIVIL WAR AND THE CREATION OF THE CONSEJO SUPERIOR DE INVESTIGACIONES CIENTÍFICAS}

The regime that resulted from the Civil War meant a return to the past for women. The gender policy imposed by the Franco dictatorship denied women any type of individual autonomy. The new civil legislation curtailed their individual rights. For practical purposes, this meant that they were relegated to a role of subordination and seclusion in the domestic sphere. For example, the Fuero del Trabajo of 1938 said, "In particular, it will prohibit night work for women and children, regulate work at home and free the married woman from the workshop and the factory."

As a direct consequence of this legislation, from 1939 on, separate registration of women and men with the government was required. Only women had to declare the name of their spouse, their profession, place of work, salary received, and number of children. Moreover, after that year, a woman was also prohibited from registering as a worker in the placement offices unless she was a family head, she was separated, her husband was disabled, or she were single. In other words, the conception of women in Spain had similarities with the Nazi ideology of Kinder, Küche, Kirche ("children, home, church").

After the coup d'etat and the subsequent military victory of Franco, the state established tight control over Spanish society. Education and the university would not be an exception. From the greater previous intellectual freedom, Spain entered a period in which the ideological agenda would be strongly marked by National Catholicism. The creation of the Consejo Superior de Investigaciones Cientificas (CSIC) in November 1939 served that purpose (Urquijo Goitia, 2007). 
The republican heritage now had a very negative value for the state, whose desire to anathematize the JAE was barely hidden (Urquijo Goitia, 2007: 261). But not all of the institutions disappeared. Once the war was over and the most urgent measures were issued regarding the purging of officials of the Republic, the intention was to normalize the situation. The Residencia de Señoritas reopened its doors in February 1940. But there were changes. As happened with the CSIC, the "re-Catholization" would be very present in this reopening, as attested in this order of January 19, 1940:

A deep-rooted Spanish tradition has been to consider Student Residences as centers of moral and religious training. The spirit of the movement is toward restoring this conception, restoring those values to their place of precedence in the life of the university student. ${ }^{2}$

The reopening of the residencia did not mean maintaining the philosophy that had inspired its creation. For this reason, it was understood that it would be officially renamed the Colegio (high school) Mayor Teresa de Cepeda. But there was one thing that effort was made to maintain. The new director, Matilde Marquina, was aware of the relevant role that the established relationships had with the International Institute for Girls in Spain (Piñón Varela 2015).

The contacts with Susan Huntington Vernon prove it, though this would seem, a priori, a contradiction of the principles of the regime. Huntington had not only directed (1910-1918) the International Institute, but during the Civil War was one of the voices that showed the most support towards the Republican exiles in New York, even allowing some refugees to stay at her home in Brooklyn (De Zulueta, 1984: 183-184).

To overcome the incongruity posed by asking for help from a person close to the exiled Republican refugees in the United States, Matilde Marquina emphasized the "independence" of the institution, although it "depends directly" on the Undersecretariat of the Ministry of National Education. In addition, as expected, she showed great interest in renewing the agreements for collaboration with the Corporation of the International Institute, which were about to expire. "We have reached the termination date of our contract with you," she wrote, "and we do not want to end it. Can we not continue on the same terms as the contract of last year?... Now having come this far, we do not want to change the conditions of the contract that has governed for so many years" (Vázquez Ramil, 2012: 308).

As it happened, relations were fluid during the dictatorship. In fact, there were reciprocal arrangements for use of space between the US institutions in Madrid and the Residencia de Señoritas. In August of 1942, the name of the residencia was changed again, this time being fixed as the Colegio Santa Teresa de Jesús.

But what concerns us here the most is delineating the role played by the CSIC in the promotion of cultural exchanges abroad. For this, we must return to the start of the dictatorship and the decision taken with respect to the educational policy that had been followed up until then by the Board for the Extension of Studies and Scientific Investigations. From its inception, the CSIC showed an interest in continuing the practices put in place by the JAE in terms of granting scholarships and grants. Both for expanding knowledge and for conducting research work in foreign centers, it did not intend to curtail the outside travels of Spanish scholars. However, cultural exchanges would not be permitted with just any country. Germany would become the host country of choice for the larger percentage of the award recipients (Delgado GómezEscalonilla, 2007: 270).

As for relations with the United States, the political context marked the road map. If, during the World War II years, the aspirations and interests of the regime were centered in Germany, the end of the war and, above all, the Nazi defeat meant a change in direction. The change entailed smoothing over the rough edges with the two great Western powers that had won the armed conflict: Great Britain and the United States. Thus, it appears to be no coincidence that the number of exchange scholars and their destinations changed significantly. The Land of Lincoln began to generate more attention, while interest in Germany fell off. The growing interest of Franco in building bridges with Washington was reflected in an increase in the amount of grant money for study and research on the other side of the Atlantic. Between 1945 and 1948, a total of 340 scholarships were awarded, of which more than a third went to the furthering of studies on US soil (Delgado Gómez-Escalonilla, 2007: 274).

\section{SPANISH-AMERICAN RELATIONS: FROM THE SPANISH CIVIL WAR TO EISENHOWER'S VISIT (1959)}

The triumph of the Francoist forces in the Spanish Civil War meant the coming to power of those sectors that traditionally had a more negative image of the United States. To the anti-Americanism that characterized a large proportion of the traditionalists and the majority of the conservative right were added the Falangists. They joined the anti-American right-wing tradition with the new wave of the European far right, where the Nazis were at the forefront. Although the United States government remained neutral toward the Spanish conflict, many Francoists perceived Washington as in fact supporting the Second Republic (Fernández de Miguel, 2012: 107). The participation of some three thousand North Americans volunteers (The Abraham Lincoln Battalion) in the Spanish contest on the side of the republican government encouraged that perception (Simkin 1997).

In March of 1942, Roosevelt appointed Columbia University professor Carlton J. H. Hayes as US ambassador to Spain (Thomàs, Carlton J. H. Hayes y el régimen de Franco 2016) (León-Aguinaga, 2014: 5). Hayes's function was to temper the pro-Axis interventionist inclinations of the Caudillo, as well as to transmit to Franco the expediency of establishing good relations with the Al- 
lies. Slowly, and forced by the unavoidable defeat of Hitler, the Caudillo was changing direction. For example, in February 1945, he began allowing the US Air Transport Command to stop in Madrid on its way to Paris and Rome (Moreno Cantano, 2008: 614). Notwithstanding, even as the regime drew to the Allies, it continued to supply Wolfram to the Nazis, looking the other way at the largescale smuggling of this material (Thomàs, 2010).

Once the war ended, the winds of world opinion blew against the regimes associates with the Axis. In that hostile atmosphere, Franco had a triple challenge ahead: the very serious economic situation of the country in the wake of the Spanish Civil War, the negative image that hovered around him because of the dangerous friendships he had with Hitler and Mussolini, and the possibility that the Allies would support Don Juan or the Spanish Republicans in exile to transform the dictatorship into a democratic system, a sentiment that was also gaining strength in some limited sectors of the Spanish army (Cardona, 2001: 101-110).

The diplomatic sanctions approved by the UN General Assembly in December 1946 against the Franco regime confirmed the need for a political rebranding of the regime's international image. The Spanish government was aware of this, and efforts to that effect were mobilized. For example, a program of reorientation of slogans was begun, even extending to the film industry (Gubern, 2006: 176-177). However, it should not be supposed that there was any decline in propaganda promoting Franco himself. Quite the contrary: when the Caudillo was in his most vulnerable moment, the cult of personality intensified. His portrait hung in just about all public buildings. Moreover, whether by coincidence or otherwise, from that same December of 1946 on the profile of Franco was stamped on the coins, with the inscription "Francisco Franco Caudillo of Spain by the Grace of God."

The UN sanctions compelled the regime to use all the means at its disposal. The No-Do would be one of the weapons of choice in this circumstance. From its inception, the new program put forward by the Franco regime was not an instrument of shock propaganda, as El noticiario español had been, but one of "building a foundation, more passive than active, without detracting from the fact that its machinery was being put at the exclusive service of a purposeful mobilization" (Sanchez-Biosca, 2006: 204-205).

But US policy in relation to Spain was beginning to change, signaled by the 1947 declaration of the Truman doctrine. Clearly, the beginning of hostilities between the two great international powers and the beginning of world bipolarization marked a turning point: the American hostility towards Franco was about to subside. Aware of this, Franco told a correspondent of the International News Service that "Spain was in optimal condition to be the best ally of the USA and that the Americans could reach an understanding with him to establish or use military bases on Spanish territory" (Ordaz Romay, 1993: 424).
From this point on, the US government would reject any plan to overthrow Franco, which in truth it had been rather dubious about even before. Washington now sought to encourage the "moderation" of the dictatorship and its modernization (Viñas, 2015: 197 y ss), for which economic credits from the private sector would later be granted. In the end, spurred both by the efforts of the pressure group led by the Spanish ambassador José Félix de Lequerica and by the international context, a approchement between the United States and Spain culminated in the signing of the Madrid Pacts of 1953.

\section{THE INCLUSION OF SPAIN IN NORTH AMERICAN PROGRAMS}

For the Franco regime, these agreements were vital, as they restored its international legitimacy and guaranteed its survival, as well as incorporating Spain into the Western defense system. "The impression was that Franco had gotten his way, reaching an agreement with the United States without any cessions of sovereignty and without submitting to European conditions" (Delgado Gómez-Escalonilla, 2003a: 246). The reality was very different, although neither the Spanish nor the American public had the details of the actual terms agreed upon (in Spain because of press censorship in Spain, and in the United states because the agreement was executive and thus did not have to go through the Senate ratification process).

During the period prior to the signing of these agreements, the American cultural presence in Spain centered on the Casa Americana (Delgado Gómez-Escalonilla, 2003b: 46). Despite the coldness that prevailed over relations between the two countries (or precisely because of this, following the logic of "soft power" described above), the United States became the main recipient of Spanish scholars. Between 1945 and 1948, 112 scholarships were granted for the furthering of studies on American soil. In that same wave of drawing closer to the Amigo americano, the CSIC re-established its ties with US counterpart organizations and institutions (Delgado GómezEscalonilla, 2003b: 52).

The lack of democratic freedoms caused Spain to be excluded from the European Recovery Program. Popularly known as the Marshall Plan, this program was accompanied by an information campaign that aimed to spread the "American Way of Life." Among the objectives: promoting access to modernity, the consumer society, technological development, and democratic ideals. Isolated from this important transatlantic link, Francoist Spain had to look for its own, more complicated path of access to the amistad estadounidense.

The initial approach and the start of negotiations toward reaching a military agreement moved slowly. It would be propitiated by a wide array of cultural activities, within so-called "public diplomacy." Progressively, Spain began to be included in cultural exchange programs. The objective of the United States was to build bridges between Spanish leaders and public opinion and thus make 
the perception of the American military presence positive. For this reason, one of the first initiatives was the implementation of the Foreign Leaders Program. Ambassador Stanton Griffis insisted on the importance of allocating funds to increase the number of beneficiaries who expanded their training in North American centers, aware as he was of the precarious position of the Spanish in fields such as education, journalism, medicine, engineering, and all of the technical careers (Delgado y Rodríguez Jiménez, 2018).

\section{THE FULBRIGHT PROGRAM AND THE SLOW INCORPORATION OF WOMEN (1959-1975)}

In the early $1950 \mathrm{~s}$, Spain was gradually becoming more integrated into the international arena. This process began with the agreements between Madrid and Washington of 1953, already mentioned. The political changes that these agreements brought about - the entry of technocrats (some being members of Opus Dei) into the government and the increased interest of US public diplomacy in Spain-allowed for inclusion in the Fulbright Program:

The result was the commencement of a reticent transformation, related to the new governments nominated by Franco. In these governments the military and the Falange people lost part of their previous power in favour of the "technocrats," generally associated with the Opus Dei. These were highly qualified officials who aimed at modernizing Spain while maintaining its political structure (Groves, et al., 2016: 173).

The signing of the Fulbright agreement occurred in October 1958; the first batch of Fulbrighters made the journey for school year 1959-1960 (Delgado, 2009).From that date until the dictator's death, the number of beneficiaries was 825 men and 201 women.

Spain's entry into international programs held greater interest for the country with respect to scientific research. For this, efforts were made to consolidate and guide Spanish science and technology, for example, the establishment of the Comisión Asesora de Investigación Cientifico Tecnológica (CEICYT) in 1958 and the Fondo Nacional para la Creación Científica in 1964. Technological development made slow progress due to the difficult relationship with the CSIC. As noted, this institution dominated research in Spain, and its nature, with a markedly Catholic orientation, slowed down scientific progress (Delgado Gómez-Escalonilla, 2007).

The inclusion of Spain in the Fulbright Program would eventually mean a signifnicant cornerstone toward modernization. To the educational consequences, we must add the political and cultural repercussions. In the former realm, a mutual understanding between Spain and the United States was fostered, following the logic of soft power (Arndt y Rubin 1993). Democratic Senator William Fulbright, who promoted the creation of this program in 1946, described his hopes this way:
High academic standards are important...but the purpose of the program is not only the advancement of science or the promotion of scholarship. These are by-products of a program whose primary aim is international understanding (Rosenzweig, 1966: 277-278). ${ }^{3}$

As noted, the Spain's entry into the program suffered a considerable delay compared to other countries in the region. This was so because in the negotiations, the Spanish delegates feared that the scholarship program would bring with it new cultural currents that would disrupt the ideological essence of National-Catholic Spain. In addition, Washington was no more in a hurry for the incorporation of the dictatorship, because the regime itself was already fighting vigilantly against any attempts at Soviet propaganda (one of the stimuli for the growth of the Fulbright program in other countries).

In establishing the foundations of the program, those involved in the negotiations soon showed some disagreement over which areas should be more considered important. The Americans favored promoting the social sciences and humanities, while the Spaniards were more interested in gaining access to American scientific knowledge. The pure and applied sciences were very necessary to a country that wanted to modernize its economy. ${ }^{4}$

According to a study of this aspect, the main difficulties suffered by the program during the first years were:

- the low academic level of some of the scholarship awardees;

- the poor command of English by a considerable number of the participants; and

- the low number of teachers and researchers within the program: most of those sent from Spain were students (Groves, et al. 2016: 176).

\section{THE WOMEN FULBRIGHTERS (1959-1975)}

With Spain included in the Fulbright circuit, Spanish women would now have a window (reopened, if we recall the work of the JAE) of opportunities to train abroad. As we have already pointed out, the Franco dictatorship wanted to impose a model of organic society with a gender policy regulated by civil legislation that denied women any type of individual autonomy and made them the axis of social morality. With this mentality, the fear on the part of the government over the influence that North American culture could exert is understandable. If during the 1920s Hollywood exported the image of the flapper, there was a change during the Cold War. In the constant quest by the American establishment to change the negative impressions of the US held in Spain, a new model of women was transmitted. The prototype of American Woman sought to replicate the norms that National-Catholicism imposed on Spanish women. In order to nuance that, the idea was to convince Spanish society that the divorce rate was not rising and that households (the family) were not decaying. The American woman, however, pre- 
sented a wider range of facets within society. Not only was she a housewife and mother, she was also a participant in the nation's political and intellectual life (Díaz Silva y Rodríguez Jiménez, 2015).

The biographical sketches that follow are drawn from documentation from the Fulbright Commission Archive. ${ }^{5}$ We are aware that any investigation of this type involves a difficult challenge: the selection of subjects. In this case, we have chosen those women who, due to their life careers, were outstanding - all this without discounting the rest of the participants. Above all, the research objective is to trace the professional careers (and other information about their life histories, if available) of the beneficiaries. To date, some interviews have been conducted with the participants, but more still need to be done, which leaves a window open for future research.

\section{WOMEN FROM SPAIN IN THE UNITED STATES}

Female participation in the Fulbright Program in Spain, from 1959 to 1975 , consisted of 201 women who benefited from one of the different scholarships offered by the program. In the same period, the number of men (828) was about four times higher. Of these, the branches of Social and Legal Sciences, together with Arts and $\mathrm{Hu}-$ manities, made up just over $82 \%$ of the total. Breaking the figures down by individual branches of knowledge, one sees women approaching $40 \%$ in one area, Arts and Humanities, as can be seen in the following graph.

On the other hand, if we look at absolute numbers, the careers most linked to cultural transfers from Spain are those in the fields of education (46), languages (14), Spanish language philology (21), modern Spanish literature (18), and social work (25).

But if the statistical data are striking in terms of the Spanish male-female relationship, this becomes even more the case if the analysis is done by comparing the US beneficiaries with the Spanish ones. The weight that literature had for the Americans is suggestive: more than half of all the women who came to Spain pursued studies in that branch.

\section{SOME EXAMPLES OF WOMEN FULBRIGHTERS}

It should be remembered that in the period studied, the number of Spanish women who went to the United States thanks to the Fulbright Program was 201. Of these, 77 belonged to the student exchange program, while the rest went as part of other subprograms. Some of the grants were set up to finance only the trip. Therefore, we will present different examples of the trajectories of the beneficiaries. To do this, we will try to take into account all the cases: people whose experience was limited to a journey of learning/improving the language; others who, after the experience, decided to stay in the United States; those who returned to Spain and continued their work (occurring in many instances with teachers); and, finally, the women who returned to Spain and advanced notably within their specialties.

The first example selected is María Luisa de Villalobos Martínez-Pontremuli. Born in 1934, this woman from Madrid benefited from the Fulbright Scholarship in 1960, when she was 26 years old. After passing through the

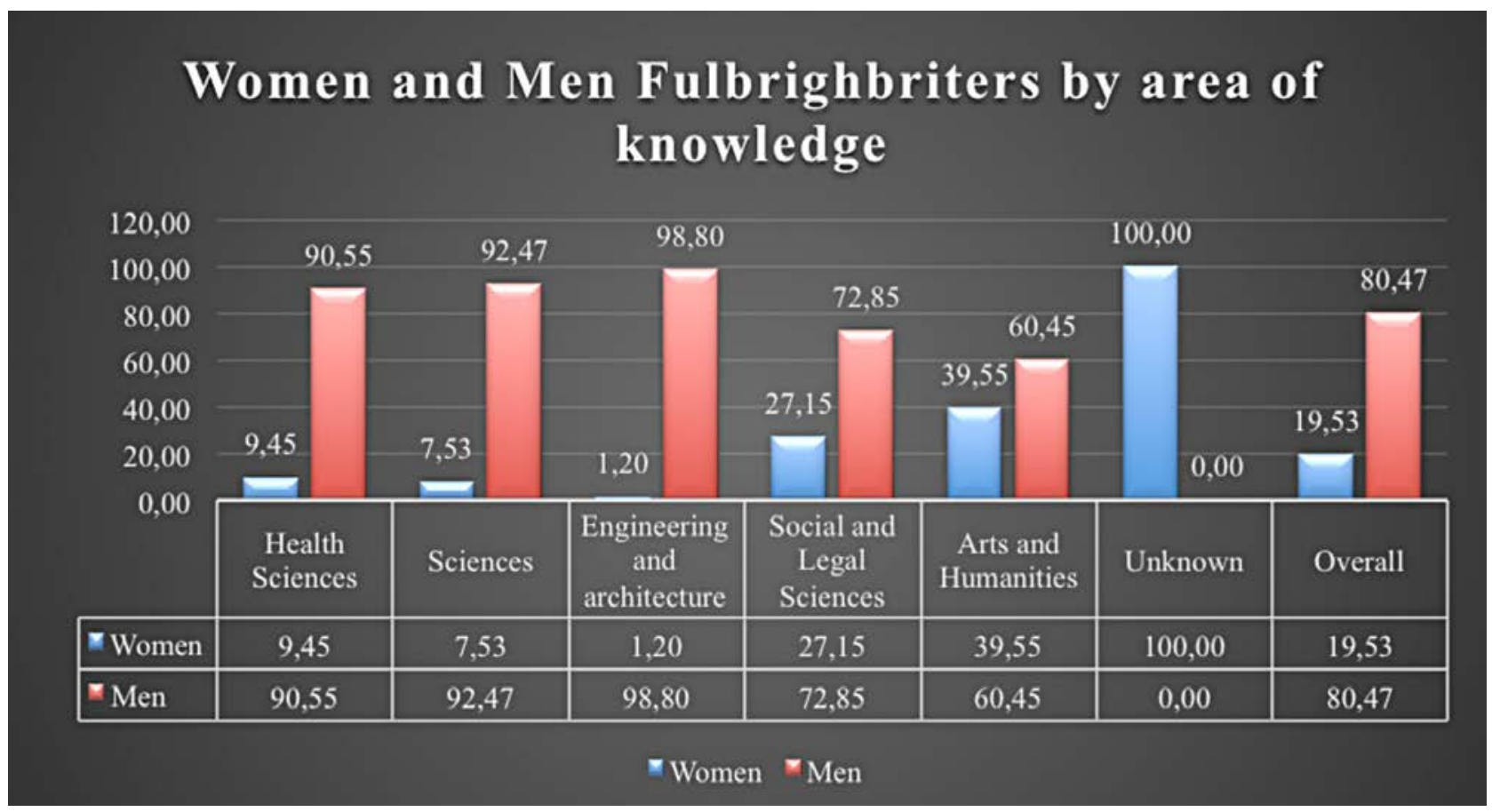

Source: Authors' own elaboration on data from the Fulbright archives. 


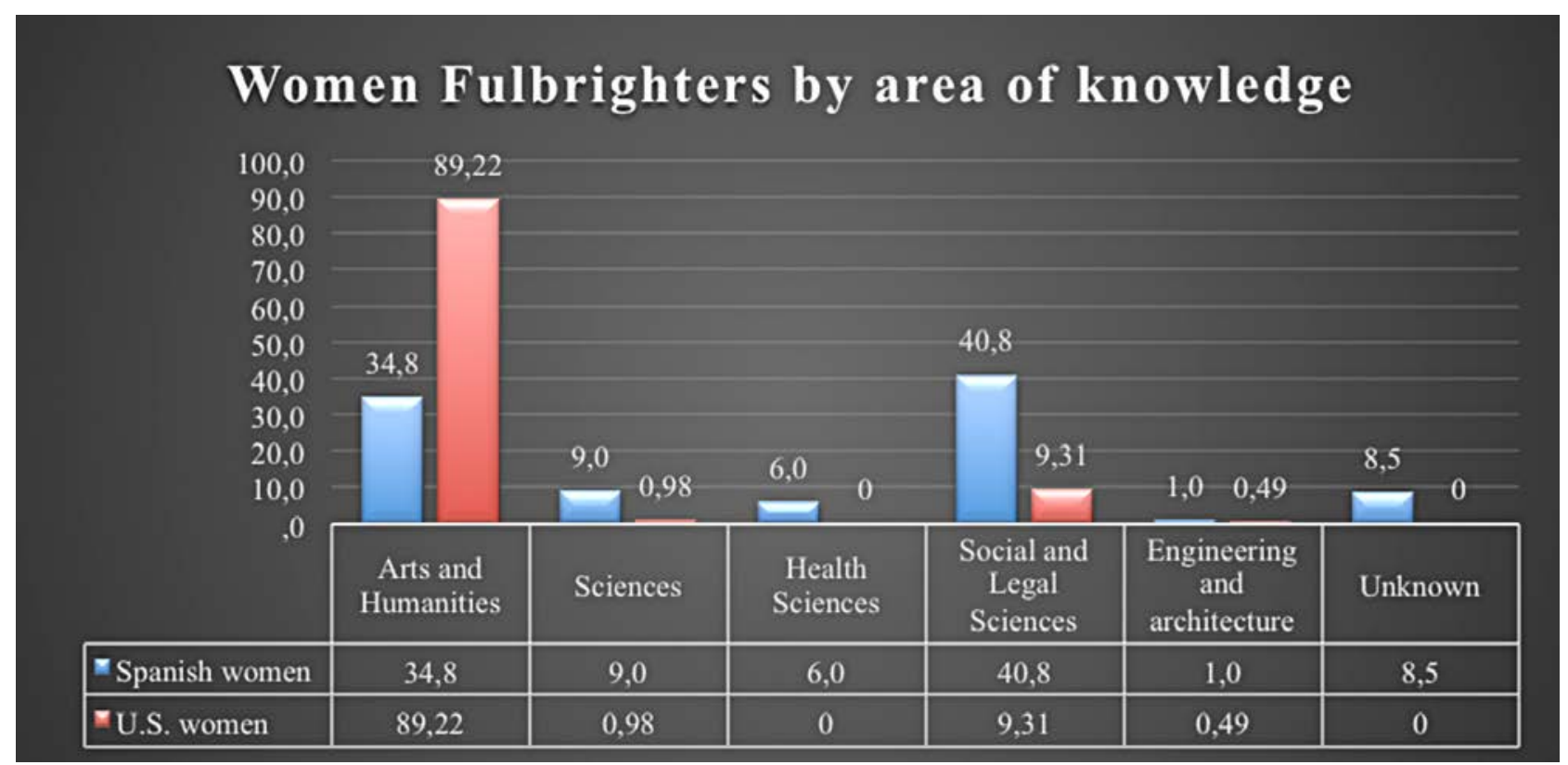

Source: Authors' own elaboration on data from the Fulbright archives.

United States, she became Professor of History at the Complutense University of Madrid. Her main line of research focuses on medieval religious iconography. Among her most outstanding works, Introduction to the World of Icons (1983, reprinted in 2000) and A Manifestation of Eastern Orthodox Christianity: The Icons (1984). ${ }^{6}$ Of even greater interest to us, for the purpose of this research, are two translations that were done much earlier. The first was in 1959, one year before benefiting from the scholarship: One Hundred Years of Evolution, a monograph by the American George S. Carter. Perhaps the motivation to make the trip to North America came from this contact with Carter. Only three years later, the same author translated the classic work of M. Michaud, History of the Crusades. It is striking that, within her short bibliography, her translations of works of an international nature were carried out around the period of the Fulbright Scholarship.

The next selected female Spanish representative in the United States is Lourdes Benería i Farré, ${ }^{7}$ who made the journey in 1961. This Catalan native, born in 1937 , is considered one of the leading specialists in economic and gender studies in connection with globalization. Thanks to her reputation in this field, she has been an expert advisor in economics with the International Labor Organization (ILO) and the United Nations Development Fund for Women (UNIFEM). Benería i Farré began her studies at the University of Barcelona, later receiving the Fulbright Scholarship to study at Columbia University in New York, where she received her doctorate in economics in 1975. Unlike in the case of Villalobos, where the legacy of her stay in the United States was barely perceived after she returned to Spain, Benería i Farré, after receiving her doctorate, was a professor at Cornell University in Upstate New York from
1987 to 2009. Among her publications, one worth mentioning is Women and Development: The Sexual Division of Labor in Rural Societies, a study published in 1982.

Also in 1961, the travel grant to Sagrario Martínez Carrera was awarded. Her story is significant to us for two reasons. First is that she did not go with the usual Fulbright scholarship, but rather with FULB-TRAVEL. This scholarship consisted in the granting of a travel voucher, so it did not include the financing of studies abroad. This subprogram was active from 1960 to 1974, with a total of 42 women benefiting from it. Her case is also of interest for the field of study that she pursued. As has already been pointed out, most of the women and of the fellows in general came from the Social Sciences and the Humanities. Sagrario, however, was in the field of chemistry. Licensed in 1948 by the Complutense University of Madrid, she received her doctorate in 1955 from the same institution. She was a professor at the CSIC and had worked in the Department of Crystallography of the Physical Chemistry Institute Rocasolano in Madrid since 1950. This department can be considered an heir to the X-Ray Section that Julio Palacios formed in 1948 at the Alonso Santa Cruz Institute. She did a postdoctoral stint at the University of Amsterdam. Although the scholarship was granted in 1961, it was in 1962 when she entered the University of Pittsburgh, Pennsylvania, where she learned electronic calculus, training that could transfer to her return to Madrid and that allowed her to advance in the study of crystalline structures. In 1974 she organized a major international conference on anomalous dispersion, with scientific personalities in attendance of the stature of Dorothy Hodgkin, winner of the Nobel Prize in Chemistry in 1964, Paul P. Ewald, and Rudolf Mössbauer, among others. She performed managerial roles and played a very 
important part in the organization of the CSIC as a member of the Scientific Advisory Committee.

With the cases of those first three women selected, we find an important contrast already. The first one seems to have made the study trip to deepen her knowledge of the language. We reach this conclusion when we consider that she promptly did those two translations and, as far as we know, had no more substantial contact with the United States. The second example shows us the opposite: a woman whose stay in America opened a professional (and possibly emotional) path for her entire life. We observe an intermediate situation in Sagrario Martínez: she benefited from her stay in North America by being able to build a successful professional future in Spain.

We turn next to three women whose area of study was literature. The first is María Elena Bravo Guerreira, who traveled on a Fulbright Scholarship in 1962. On her curriculum vitae, she has two awards for excellence as a teacher and numerous contributions to the dissemination of Spanish culture with activities such as: founding member, member of the Board of Directors, and president of the Spanish Midwest Association; founding member and board member of the Spanish Association of Spanish Doctors and Graduates in the United States (ALDEEU); board member of the Hemingway Foundation in Oak Park, Illinois; collaborator and advisor of the Chicago Latino Film Festival; and collaborator in the founding of the Cervantes Institute in Chicago. In 1995 Bravo received the Lady's Bow from the Order of Isabel la Católica. In this case, we are fortunate that she was interviewed, as it provides us with record of her Fulbright experience. ${ }^{8}$ She studied French and English at the University of Salamanca. She also went to St. Andrews University. In that interview, she explains that after her visit, she was "dazzled" by the University of North Carolina at Chapel Hill, where she did postgraduate studies in English and North American Literature. Her academic life was connected to both countries, because after taking her master's in the United States, she received her doctorate from the Complutense University. Doctorate in hand and influenced by her personal situation (she married a Scottish Hispanic scholar), she continued her career in the United States as a professor at several Midwestern universities: University of Illinois, Urbana-Champaign; University of Michigan, Ann Arbor, Residential College; University of Illinois, Chicago; University of Chicago; and Dominican University.

In the year 1963, Ana María Martín Úriz received the FULB-TRAVEL grant. $^{9}$ A specialist in the relationship between English and Spanish, her academic career led her to become professor at the Faculty of Philology of the Autonomous University of Madrid, of which she is currently an honorary professor in the Department of English Philology.

Of similar interest is the trip of María Josefa Canellada Llavona. This Asturian born in 1912 can be considered one of the most brilliant women at the academic levels that we discuss here. She began her teaching work in research and teaching centers in the 1940s. She served in the Menéndez y Pelayo Institute of the Superior Council of Scientific Research (1940-1946) and in the Phonetics Laboratory of the University of Coimbra with Professor Armando de Lacerda (1942), and was a professor at the Faculty of Philosophy and Letters of the University of Salamanca (1946-1948) and its Courses for Foreigners (1952-1958), also collaborating in the Philology Section of the College of Mexico (1960). In addition, she worked as a researcher at the Menéndez Pidal Seminary (19581962), as a professor of Spanish Phonetics at Middlebury College (1964), professor of Spanish phonetics in the courses of the University of New York in Spain (19661974), professor in charge of the course in the Faculty of Philosophy and Letters of the Universidad Complutense (1970-1973), professor of the Spanish Language and Literature course for Spanish teachers in the English-speaking countries of the Caribbean (1974-1975), professor of Spanish-Filipino courses for teachers of Spanish (19761983), editor of the Diccionario manual de la Real Academia Española (1979-1988), and guest professor at the Romansk Institute of the University of Copenhagen (1981). Considering this curriculum, we can affirm that her Fulbright-sponsored trip to the state of Vermont was a turning point in the career of an already brilliant professional. And, in her quest to deepen the study of Spanish phonetics, she endeavored to encourage the study of Spanish on American soil.

Dedicated to the field of education, Mercedes ÁlvarezLovell traveled to the United States in 1963. But she did not do it with the regular Fulbright Scholarship. Mercedes benefited from the FTD, dedicated to secondary education teachers. a program that in spite of its short existence (1962-1966) had a not-insignificant relevance. Its function consisted in the training of those Spanish teachers who had to face Spanish basic education. The Fulbright Commission was aware that training should not be limited to outstanding university students, but also to those teachers who ultimately trained a large number of citizens in high school education. In this case, receiving the scholarship had immediate consequences. Just after arriving back from the United States, she started working. According to the official document issued by the Ministry of National Education, she was appointed full professor of English at the Ramiro de Maeztu high school in Madrid. ${ }^{10}$

Finally, we consider Manuela Beatriz Mena Marqués. Born a Madrilenian in 1949, she was one of the 13 women beneficiaries of the Cultural Cooperation Program between Spain and the United States. Also known as Non Military Agreements (NMA), this program arose from the signing of the "friendship agreement" by that name, which was institued on August 6, 1970. In Chapter II of the pact, it was established that both governments would agree to expand the exchanges in the cultural and educational fields, an extension that included professors, researchers, scientists, and intellectuals, especially from the fields of natural and economic sciences and of the language and culture of both countries. The purpose of the program was to prepare Spanish university professors and CSIC researchers. It was included in the Fulbright Pro- 
gram because the Ministry of Foreign Affairs its implementation to the Fulbright Commission.

In the specific case of Manuela Beatriz, she took advantage of the trip made in 1975 to outline her thesis. She received her doctorate in 1976 from the Complutense University, specializing in Italian drawing and painting of the seventeenth century. But she had already been teaching. From 1971 to 1981 she taught at the Autonomous University of Madrid, where she obtained, by competitive examination, the position of Conservator of Drawings and Prints of the Prado Museum. At the museum, she was assistant director of Conservation and Research from 1981 to 1996 and member of its Board of Trustees from 1991 to 1996. She has organized numerous exhibitions, among which Murillo (1982), in collaboration with the Royal Academy of London, and Monsters, Dwarves and Buffoons at the Habsburg Court stand out. She also participated in the organization of the exhibition Goya and the Spirit of the Enlightenment (1989), in collaboration with the Museum of Fine Arts in Boston and the Metropolitan Museum of Art in New York. She coordinated and participated in the exhibitions of Velázquez and Ribera (1990 and 1992, respectively), and provided the academic expertise, along with Juliet Wilson-Bareau, for the exhibition Goya: The Whim and Invention (1994). She was also curator of exhibitions of Italian drawings of the seventeenth (1983) and eighteenth centuries (1991), Cabinet Paintings, Sketches and Miniatures, Rafael and Spain (1985), Sebastiano del Piombo and Spain (1995) and Manet in the Prado (2003). Unfortunately and so far, we do not have information about the center where she stayed in the United States, but it seems clear that it had an important influence in her career.

During the post-Franco democratic years, the distribution by sex of the Fulbright beneficiaries was rebalanced, reaching even more women than men in some years. We are undertaking a research path barely traveled. The brief biographical sketches of Spanish Fulbrighters presented here leave much to be continued. There were more than two hundred Spanish women who, during the Franco period, had the opportunity to participate in that transatlantic experience. This initial approach to the subject allows us to surmise that the travel to, and study in, the United States constituted an important spur for their later professional development. The details of those stories have not been scrutinized yet ${ }^{11}$. We hope this texte could serve as the first stone in that needed research.

\section{NOTES}

1 For more details along these lines, see (Delgado Gómez-Escalonilla, Lorenzo (1994): 266-267. El factor cultural en las relaciones internacionales: Una aproximación a su análisis histórico).

2 BOE 52, Wednesday, February 21, 1940; 1312

3 Rosenzweig, Richard (1966): 277-78. "Foreign Policy and Education: A Confusion of Purposes" Journal of Higher Education 37. Quoted in "The United States Communicates with the World: A Study of U.S International Information and Cultural Programs and Activities". 25/08/1975. NARA RG 306, Post Publications, 1953-99, box 65
4 "Commission for Educational Exchange between the United States of America and Spain. Annual Program Proposal, October 1958 to June 1959". AGA, box 54/10519. "Commission for Educational Exchange between the United States of America and Spain. Minutes of the meeting." 09/01/1962. ACFE, box 1. "Commission for Educational Exchange between the United States of America and Spain. Minutes of the meeting." 09/02/1965. ACFE, box 2 and "Commission for Educational Exchange between the United States of America and Spain. Annual Report," October 8, 1968, AGA, caja 54/10568.

5 The documents in the Archive of the Fulbright Program in Spain began to be organized in 2004 with a triple objective: to rescue the memory of the institution, to serve as a source of information abroad (to research); and to institute an internal document management service. (De la Hoz 2016).

6 Her literary works are in the database of the Biblioteca Nacional de España: http://datos.bne.es/persona/XX985427.html (consulted August 22, 2017).

7 The abridged academic curriculum can be found at http://www. ccoo.cat/pdf documents/Lourdes\%20Beneria.pdf (consulted August 22, 2017)

8 http://asoc-fulbright.es/2013/03/14/fulbright-maria-elena-bravo/ (consultado 22/08/2017).

9 https://portalcientifico.uam.es/ipublic/agent-personal/profile/ iMarinaID/04-260008/name/MARTIN\%20URIZ,\%20 ANA\%20MARIA (consultado el 22/08/2017).

10 A digital image of the original document can be found at http://1.bp.blogspot.com/-KKoOTphgD8Q/VjIJ9IgElEI/ AAAAAAAA2vo/ftgSNs1IIk8/s1600/lovell0001.jpg (consulted August 22, 2017).

11 If any of the readers of this text happen to know some of these women, we will be delighted to get some more info, and/or eventually interview them, if it was possible.

\section{REFERENCES}

Arndt, R, and D Rubin (1993) The Fulbright Difference, 19481992. New Brunswick. Transaction Publishers

Benso Calvo, Carmen (2003) "Exclusión, discriminación y resistencias: el acceso de la mujer al sistema educativo (18331930)". In Xénero e educación social, edited by E Jato Iglesias and L Iglesias da Cunha. Santiago de Compostela. Edicións Laiovento.

Cacho Viu, Vicente (2017) "La Institución Libre de Enseñanza, desde dentro". Revista de Libros, junio 1, 1997. http://www.revistadelibros.com/articulos/la-institucion-libre-de-ensenanza-y-su-ambiente-de-antonio-jimenez-landi (accessed noviembre 22, 2017).

Cardona, Antonio (2001) Franco y sus generales: la manicura del tigre. Madrid. Temas de Hoy.

Cuesta, Josefina, María José Turrión and Rosa María Merino (2016) La Residencia de Señoritas y otras redes culturales femeninas. Salamanca. Ediciones Universidad de Salamanca.

De Zulueta, Carmen (1984) Misioneras, feministas, educadoras. Historia del Instituto Internacional. Madrid. Editorial Castalia.

De la Hoz, Patricia (2016) "El Archivo de la Comisión Fulbright y el estudio del intercambio educativo y cultural entre España y Estados Unidos". La Historia: Lost in translation? XIII Congreso de la Asociación de la Historia Contemporánea, taller 16. El factor internacional de la modernización educativa, cientifica y militar en España: 145-164.

Delgado Gómez-Escalonilla, Lorenzo (1994) "El factor cultural en las relaciones internacionales: Una aproximación a su análisis histórico". Hispania LIV, no. 186: 257-278.

Delgado Gómez-Escalonilla, Lorenzo (2003a) "¿El 'Amigo Americano'? España y Estados Unidos durante el franquismo." Studia Historica. Historia Contemporánea, no. 21: 231-276.

Delgado Gómez-Escalonilla, Lorenzo (2003b) "Las relaciones culturales entre España y Estados Unidos, de la Guerra Mundial a los Pactos de 1953". Cuadernos de Historia Contemporánea, no. $25: 35-59$ 
Delgado Gómez-Escalonilla, Lorenzo (2007) "Dimensión internacional del CSIC". In Tiempos de investigación. JAE-CSIC, cien años de ciencia en España, edited by Miguel Ángel Puig-Samper; 269278. Madrid. Consejo Superior de Investigaciones Científicas.

Delgado Gómez-Escalonilla, Lorenzo (2009) "Viento de Poniente" El Programa Fulbright en España, 1958-2008. Madrid. Editorial Empresarial-AECID.

Delgado Gómez-Escalonilla, Lorenzo, and Francisco Rodríguez Jiménez (2018) "España en el 'Imperio informal' norteamericano: captación de líderes y redes de influencia”. In Estados Unidos, España y el nuevo orden científico mundial, edited by Lino Camprubí, Xavier Roqué and Francisco Sáez de Adana: 191-214. Madrid. Catarata.

Díaz Silva, Elena, and Francisco Javier Rodríguez Jiménez (2015) "Recepción, conflictos e influencias del American Woman Model en España, 1945-1960". In ¿Mujeres Sabias? Mujeres universitarias en España y América Latina, edited by Josefina Cuesta Bustillo, María Luz de Prado and Francisco Javier Rodríguez Jiménez: 301-334. Limoges. Presses de l'Université de Limoges.

Dizard, Wilson (2004) Inventing public diplomacy: the story of the US Information Agency. Boulder (Colorado). Lynne Reinner Publishers.

Fernández de Miguel, Daniel (2012) El enemigo yanqui. Las raíces conservadoras del americanismo español. Madrid. Genueve Ediciones.

Folguera Crespo, Pilar (1997) "Revolución y Restauración. La emergencia de los primeros ideales emancipadores (18681931)". In Historia de las mujeres en España, edited by Elisa Garrido González: 451-492. Madrid. Síntesis.

Formentín Ibáñez, Justo, and María José Villegas (2007) "Las pensiones de la JAE". In Tiempos de investigación. JAE-CSIC, cien años de ciencia en España, edited by Miguel Ángel PuigSamper: 95-102. Madrid. CSIC.

Groves, Tamar, Estrella Montes, and Francisco J Rodríguez Jiménez (2016) "Gender, the Fulbright Program and Women careers during the Franco regimen". In Donne e Scienza Dall'Esclusione al protagonismo consapevole, edited by Antonella Cagnolati and Sandra Rossetti: 169-190. Roma. Aracne.

Gubern, Román (2006) "La Guerra Civil vista por el cine del franquismo". In Memoria de la Guerra y del Franquismo, edited by Santos Juliá: 163-196. Madrid. Taurus. Fundación Pablo Iglesias.

La Porte, Teresa (2007) "La diplomacia pública americana: lecciones para una comunicación internacional". Comunicación y Sociedad XX, no. 2: 23-59.

León Aguinaga, Pablo (2010) Sospechosos habituales. El cine norteamericano, Estados Unidos y la España franquista, 19391960. Madrid. CSIC.

León Aguinaga, Pablo (2014) "The Trouble with Propaganda: the Second War, Franco's Spain, and the Origins of US Post-War Public Diplomacy". The International History Review; 1-24.

Magallón Portolés, Carmen, and María Jesús Santesmases Navarro (2007) "Mujeres de ciencias en Madrid: Entre el prejuicio y el orgullo". In El Madrid de las mujeres: avances hacia la visibilidad (1833-1931), edited by Valentina Fernández Vargas: 177200. Madrid. Consejería de Empleo y Mujer.

Mangini, Shirley (2001) Las modernas de Madrid. Las grandes intelectuales españolas de la vanguardia. Barcelona. Ediciones Península.

Melissen, Jan (2005) The New Public Diplomacy: Soft Power in International Relations. New York. Palgrave.

Molero Pintado, Antonio (1985) La Institución Libre de Enseñanza: Un proyecto español de renovación pedagógica. Madrid. Ediciones Anaya.

Moreno Cantano, Antonio César (2008) Los Servicios de Prensa Extranjera en el Primer Franquismo (1936-1945). Alcalá de Henares. Tesis doctoral.
Niño, Antonio (2009) "Uso y abuso de las relaciones culturales en la política internacional". Ayer 3, no. 7: 34-36.

Noya, Francisco Javier (2007) Diplomacia pública para el siglo $X X I$. Barcelona. Ariel.

Nye, Joseph (2004) The Decline of America Soft Power. New York. Public Affairs.

Ordaz Romay, María (1993) "La imagen de España y el Régimen de Franco a través de la prensa anglosajona de Estados Unidos entre 1945 y 1950". In El régimen de Franco, 1936-1975: política y relaciones exteriores. Edited by Javier Tusell: 415-427. Madrid. UNED.

Piñón Varela, Pilar (2015) Go West Young Woman! Redes trasatlánticas e internacionalismo cultural. Las mujeres como protagonistas del intercambio académico entre España y los Estados Unidos (1919-1939). Tesis Doctoral. Madrid. UNED.

Poveda Sanz, María (2014) Mujeres y segunda enseñanza en Madrid (1931-1939). El personal docente femenino en los institutos de bachillerato. Tesis Doctoral. Madrid: Universidad Complutense de Madrid.

Puig-Samper, Miguel, Consuelo Naranjo Orovio, and Dolores Luque (2002) "Hacia una amistad triangular: las relaciones entre España, Estados Unidos y Puerto Rico". In Los Lazos de la cultura. El Centro de Estudios Históricos de Madrid y la Universidad de Puerto Rico, 1916-1939, edited by Consuelo Naranjo, Dolores Luque and Miguel Puig-Samper: 121-151. Madrid. CSIC-Universidad Puerto Rico.

Rodríguez, Moisés (2015) "El impacto del cine norteamericano en la mujer española, 1914-1936". In Mujeres de cine: ecos de Hollywood en España, 1914-1936, edited by Diego Mayoral and Carlos Pérez: 104-129. Madrid. Ministerio de Asuntos Exteriores y de Cooperación. AECID.

Rosenzweig, Mark Richard (1966) "Foreing Policy and Education: a confusion of purposes". Journal of Higher Education 37, no. 5: $277-280$.

Sánchez, Isidro (2012) Educación, Ciencia y Cultura en España: Auge y colapso (1907-1940). Pensionados de la JAE. Ciudad Real. Ediciones Castilla-La Mancha.

Sanchez-Biosca, Vicente (2006) "Los Lugares de la Memoria en el No-Do". In Memoria de la Guerra y del Franquismo, edited by Santos Juliá: 197-218. Madrid. Taurus. Fundación Pablo Iglesias.

Simkin, John (2017) Spartacus-Educational. 1997. http://spartacuseducational.com/SPlincoln.htm (accessed Marzo 27, 2017).

Thomàs, Joan María (2010) La batalla del Wolframio: Estados Unidos y España de Pearl Harbour a la Guerra Fría (1941-1947). Madrid. Cátedra.

Thomàs, Joan María (2016) "Carlton J. H. Hayes y el régimen de Franco". In Guerra Civil y franquismo. Una perspectiva internacional, edited by Raanan Rein and Joan María Thomàs: 6178. Zaragoza. Prensas Universidad de Zaragoza.

Thompson, J.B. (1998) Los media y la modernidad. Una teoría de los medios de comunicación. Barcelona. Paidós.

Urquijo Goitia, José Ramón (2007) "Ruptura y creación. Primeros años”. In Tiempos de investigación. JAE-CSIC, cien años de ciencia en España, edited by Miguel Ángel Puig-Samper: 259268. Madrid. Consejo Superior de Investigaciones Científicas.

Vázquez Ramil, Raquel (2012) Mujeres y educación en la España contemporánea. La Institución de Libre Enseñanza y la Residencia de Señoritas. Madrid. Akal.

Viñao, Antonio (2004) Escuela para todos. Educación y modernidad en la España del s. XX. Madrid. Marcial Pons.

Viñas, Ángel (2015) La otra cara del Caudillo. Mitos y realidades en la biografía de Franco. Barcelona. Crítica.

Zulueta, Carmen de, and Alicia Moreno (1993) Ni convento ni college. La Residencia de Señoritas. Madrid. Publicaciones de Residencia de Estudiantes. 